\title{
Sohrab Sepehri's Imaginative Voyage from Negative Romanticism to Positive Romanticism in his Cycles of Poems
}

\author{
Mohammad Hussein Oroskhan (Corresponding author) \\ Department of English Literature, Faculty of Humanities, Vali-e-Asr University, Rafsanjan, Kerman, Iran \\ E-mail: h.araskhan@yahoo.com \\ Esmaeil Zohdi \\ Department of English Literature, Faculty of Humanities, Vali-e-Asr University, Rafsanjan, Kerman, Iran \\ E-mail: esmaeil_zohdi@yahoo.com
}

Doi:10.7575/aiac.alls.v.5n.6p.227

URL: http://dx.doi.org/10.7575/aiac.alls.v.5n.6p.227
Received: 04/09/2014

Accepted: 31/10/2014

\begin{abstract}
Romanticism extended to different countries around the Europe in eighteenth and nineteenth century. This school not only includes European countries but also countries outside the continent like Iran. Similarly, Romanticism developed some of its features out of Iranian contemporary literature. Sohrab Sepehri, the contemporary Iranian poet, has always been at the center of Romanticism investigation in Iran. Regarding Morse Peckham's view of Romanticism, this could be inferred that Sepehri has made a voyage from the "static mechanism" to "dynamic organicims". Sepehri's change of view causing this journey was his acquaintance with the Far Eastern mysticism. Therefore, the present study aims to investigate this phase shifting by focusing on its effect on his poems.
\end{abstract}

Keywords: Soharab Sepehri, static mechanism, dynamic organicism, romanticism

\section{Introduction}

Romanticism designates a literary and philosophical theory which situates the individual at the center of all life and experience. By situating the man at the center, it focuses on man's unique feelings, attitudes and experiences. This conception was opposed to the Classism and Neo-Classism of the preceding ages. Romanticism has promoted some heated debates among the critics and it has been rather difficult to provide one definable explanation of Romanticism. In fact, the numerous definitions have led to a chaos of a certain definition.

In this chaotic realm of definition, Arthur O. Lovejoy(1962) believes that Romanticism has meant different things in different countries and that even in a single country it is often used in the conflicting senses. Therefore, in his article "On the Discrimination of Romanticisms", he expands on the different definition of this movement and finally acknowledges that: "The word 'Romantic' has come to mean so many things that, by itself, it means nothing"(p.66). He later devoted a considerable effort to come up with a single definition of Romanticism but asserted that we should only discuss Romanticism and study each different trend separately. Therefore, he proposed that the term be used in plural.

However, Lovejoy's ideas were greatly challenged by theories of another well-known critic of Romanticism, Rene Wellek (1962). He believes different ages can be classified with different literary periods. In his essay, "The Concept of Romanticism in Literary History" he categorizes literary periods as ". . . a time section, dominated by a system of norms, standards and conventions"(p.277). In his view, the classification of different periods is quit valid as he has previously expressed it in his book, Theory of Literature. As he more pondered on this idea, he shaped a more organized definition of Romanticism and played a central role in this progression. Thus, he could be considered as the one who has offered us the most suitable definition:

"If we examine the characteristics of the actual literature which called itself or was called 'Romantic' all over the continent, we find throughout Europe the same conception of poetry and of the workings and nature of poetic imagination, the same conception of nature and its relation to man, and basically the same poetic style; with a use of imagery, symbolism, and myth, which is clearly distinct from that of $18^{\text {th }}$ century NeoClassicism." (p.193)

The core of what he elaborated on could be consisted of three fundamental elements: ". . imagination for the view of poetry, nature for the view of the world, symbol and myth for poetic style"(p.196).Later on, Morse Peckham juxtaposed their ideas to come up with one of his own. In his article, "Toward a Theory of Romanticism", as the title signifies, he tries to offer a rather coherent definition of the term which can help us have a better understanding of the properties of this movement:

"If the universe is constantly in the process of creating itself [As he believes that the philosophy of Romanticism stands against the mechanistic perception of the previous century] the mind of man, his imaginative power is radically creative."(p.238) 
Furthermore, Peckham (1962) discusses two different states that one experiences and how one is replaced with another. "Romanticism is the revolution in the European mind against thinking in terms of static mechanism and redirection of the mind to thinking in terms of dynamic organicism"(p.240). Peckham chooses dynamic organicim to place cardinal importance on imperfection and change. In his view, the term Romanticism can be defined as the redirection of the static mind towards "change, imperfection, growth, diversity, the creative imagination, and the unconscious."(p.240)

Peckham has given high priority over "dynamic organicims" in his definition of Romanticism. Moreover, he has devised the term "positive romanticism" to be assigned to those works which has applied "dynamic organicism" not only in its fully developed degree but also in its incomplete way. However, in his study of the works of Byron, he found out that term "positive romanticism" is worse that useless. Therefore, he decided to solve this matter by adding "negative romanticism" as a new term to his previously coined one.

Though Peckham aimed at unifying the previous and diversified theories of Romanticism to a single one, he himself diversified it more. He considers "negative romanticism" as a necessary complement to "positive romanticism". Then he briefly elaborates on the "negative romanticism" as "the expression of the attitudes, the feelings(omitted the commas) and the ideas of a man who has left static mechanism but has not yet arrived at a reintegration of his thought and art in terms of dynamic organicism."(p.242)

With this respect, Sohrab Sepehri, the contemporary Iranian poet, can be considered as a poet who has been left in a static mechanism in "Death of Colors" (omitted the commas) which is his first collection of poems (omitted the commas) and experienced a situation of "spiritual death"(p.243). During that time, he seemed to be in period of doubt and despair and did not enjoy the company of nature in those poems. However, his interest in nature increases when he became familiar with Boddhism. This new tendency affected his outlook toward nature and life. Ashouri et al. (1992) has also mentioned the influence of Far Eastern mysticisms on the poet's interest in nature (p. 26). From 1953 on, and accompanying the publishing of "The Life of Dreams" (omitted the commas) Sepehri's attitude toward life is changed dramatically. He has evaded using such symbols as night, darkness, loneliness and silence of "Death of Colors" and leaned more toward an optimistic outlook. He does not seem to be a wanderer anymore whose feet are stuck in "the pitch black of night" (Sepehri, 2007, p. 12). Sepheri embarks on an imaginative voyage and his voyage from negative romanticism toward the positive one is culminated in his famous poem "Traveler". In this poem, which is of highest caliber, Sepehri has achieved the truth and is not bewildered anymore. He has truly shifted from his "static mechanism" in "Death of Colors" to "dynamic organicism" in his "Traveler".

As Peckham believes "organicism includes dynamism, for an organism must grow or change qualitatively"; evidently Sepehri has changed from the time he has written "Death of Colors" to the time he reached his highest level in writing "Traveler". Thus, through analyzing the poems of Sepehri, the present study explicates Sepehri's journey from "static mechanism" to "dynamic organicism" in his cycles of poems.

\section{Romanticism in Sohrab Sepehri}

Sohrab Sepehri has been a contemporary Iranian poet (1928-1980). He is among the famous poets of the new generation which appeared after Nima Youshij. He was a notable modern poet and a painter. He is frequently deemed as one of the five famous modern Persian poets who have practiced and developed "New Poetry" (a sort of poetry which is not abide by the traditional system of meter or rhyme); the others being Nima Youshij, Ahmad Shamlou and Mehdi AkhavanSales.

During the last few years, his works have been extensively discussed from different perspectives. Each critic has found out a different trend in his works. The reason behind this much of various researches could be his different journeys from east to west. These journeys, as Dr. Zarabihha (2004) asserts" . . helped him to broaden his ideology" (p.98).In this regard, M. Farzan (entered a space) (1984) mentioned that Sepehri's poetry is featured with "Neo-sufic" elements. He discusses his poetries from a purely Sufi point of view, interpreting many words such as, 'darkness', 'light', 'friend' (omitted and) etc. as mystic sufi terms in the traditional sense. Sirus Shamisa (entered a space) (1993) believes that "Sepehri's philosophy of poetry is leaning towards the school of Krishna Murti, though this could not be inferred that they have met each other"(p.14).

Also, there has been some works comparing Sepehri with great world writers. In this respect, Dr. Meghdadi (entered a space) (1998) has carried out an extensive research by comparing Sepehri with Donne, Coleridge, Whitman, Emily Dickenson, Joseph Conrad, Eliot, Kafka, Frost, Sartre, Camus, Farrokhzad, Khayyam, Hafez, Mowlana, Nima, and Bible. This work shows the extents of which Sepehri's poems are diversified. Like any other artist of world caliber, his works transcends both his nationality and religion, therefore; there is no wonder to see the elements of English Romanticism in his poetry.

By considering the academic journal articles and publication in Iran, one point quite is made quite clear. There has not been sufficient investigation about Romanticism in Sohrab Sepehri in Farsi, although a few attempts have been undertaken to trace the Romantic Movement in Iran. Masoud Jafari (2007) is the most notable one to have traced the Romantic Movement in contemporary Persian poetry. In his book, A Survey of Romanticism in Iran: From Constitutional Revolution to Nima, he has divided Romanticism in Iran to three distinct periods: the first one starts by Constitutional Revolution and ends with the coronation of Reza Shah, the second period is the Age of Reza Shah (omitted the commas) and the last one is the fifth and sixth decades of twentieth century. According to his division, Sohrab Sepehri can be located in the third group. However, he has not focused on the third period, and only discussed the beginning of Romanticism up to the second period which is the time of Nima. Moreover, he has considered the 
poem "Afsaneh" by Nima as the first truly Romantic poem of Persian language. But he has not mentioned or discussed the third period of his division which includes poets like Ahmad Shamlou, Mehdi Akhavan-Sales, Frough Farrokhzad and Sohrab Sepehri. Nonetheless, he believes that "During the third period, there are various literary trends due to the turbulent time but a trace of Romanticism can be revealed in the prominent poets of the time".

Similarly, Dr. Ali Taslimi (2004) devotes a chapter of his book, Points in the Contemporary Persian Literature or Gozarehayee Dar Adabiate Moasere Iran, to Romanticism and its development in Iran (omitted the commas) and defines Romanticism as "The fight against aristocratic, pedantic language of the past and thus turning toward sensitivity and individuality of feelings... The Romantics were more interested in the internal world" (p.16). He keeps the tract of Romanticism with such a definition in Iran and categorizes the poets according to different types of Romanticism and puts Sepehri, along with Forogh Farokhzad, Simin Behbahani and a few other poets in the category of Simple Romantics.

Akram Pouralifard (2003) in her article "European Romanticism and Modern Persian Poetry" claims that the overall attitude of the modern Persian poetry regarding Nature is totally against that of the former poets. In this regard, "The attitude shows a meaningful similarity with that of the French and English poets such as Lamartin and William Wordsworth"(p.88). As it shows, the prominent feature which distinguishes the poets of new generation from the former ones is their attitude toward nature which is so similar to the Romantic poets of Europe.

Ali Khazaeefar (2006), for example, in his article "Wordsworth and Sepehri: Two Pantheistic Poets" has tried to have a comparison between William Wordsworth's "Tintern Abbey" and Sohrab Sepehri's "Water's Foot-Steps" or " Sedaye Paye Aab." He asserts that" Sohrab is a Romantic poet. . Nature in Romanticism is depicted as a temple and becomes a mirror to see the face of God in it" (p.70). He has focused on the poetics of nature in Wordsworth to claims that it is the best way to reach a better understanding of Sepehri. In fact, the role of nature in Sepehri's poetry is as prominent as it is in English Romantic poets especially William Wordsworth.

Furthermore, Shariati Rad et al. (2014) in their article "Nature as the Source of Wisdom in Sepehri and Wordsworth's Poetry" have considered the role of nature on the poems of these two poets. They have not explicitly considered Sepehri as a romantic poet, however, by considering the common elements of Sepehri and Wordsworth, they have implicitly hold Sepehri and Wordsworth in the same place. As they have claimed that both poets are advocates of human rights against the established rules, religion, contracts and whatsoever distances human with their origins and nature, they have implicitly categorizes Sepehri as a romantic poet.

In this respect, Hosseini (2000) has claimed Sepehri to be a romantic poet. He believes that the glorification of nature is one of the main elements of Romanticism. And as Sepehri's poetry is filled with such glorification, he can be considered a romantic poet. Sepehri has felt God or the spirit of world in nature in the same way; Rene Wellek (1962) has described Wordsworth's philosophy of nature as "Animated, alive, filled with God or the spirit of the World"(p.197). As Hosseini (2000) writes, "for a Romantic poet nature has a spirit; it is animate" (p. 13). Therefore, this can be verified that Sepehri can be compared with Romantic poets and also retains some of its features.

This could be easily inferred that the Romantic Movement has existed in its special form in Iran, during the years of the appearance of the new generation of the poets after Nima Ushij. Sohrab Sepehri can be aptly situated into such category. Sepehri is endowed with a distinct attitude toward nature which makes him notable among his contemporary. As Dr, Taslimi (1994) mentions:

What has been stated as something different in the poetry of Sohrab Sepehri is his unique, personal and harmonious thought. His idealistic and shocking view of Nature (omitted the commas) as opposed to the usual and non-symbolized views of the others (omitted the commas) which shapes the whole structure of his poetry. (p.139)

Nature is the guide for him that could teach the truth better than any other teacher. This fact is quite evident in most of his poems other than his first book "Death of Colors". In his first book, he seems to be a stranger in the nature. He does not feel liberated and connected to nature but feeling to be trapped in an enclosed space. But how is it possible to trace Romanticism in his first collection of poetry, if he had a hostile attitude toward nature.

As Morse Peckham (entered a space) (1962) used Negative Romanticism to solve Byron; "Positive romanticism cannot explain Byron; positive romanticism is not enough. To it must be added the term "negative romanticism"(p.250). We could also refer to the concept of Negative Romanticism to solve the mystery of the first collection of Sepehri's poetry.

\section{Negative romanticism in Sohrab Sepehri}

Sepehri's poems have been published in a collection entitled The Eight Books (Hasht Ketab). Considering his poems shows the manifold use of the natural elements. This could be inferred that nature is an integral part of his poetry. He is mostly making the best use of the Nature and his poems are filled with positive reference to the presence of Nature. However, his first book is an exception. This book shows his negative attitude toward nature. He is not considering nature as a guide and teacher of his life in this book whereas he feels to be lost and frustrated in it. If we consider the outcome of Sepehri's poetic career as a cycle, this shifting of perspective on nature could be determined clearly after his first book when he became familiar with mysticism. At this point, our aim is to explore Sepehri's situation of his first book which is so dark and frustrated prior to his familiarity with mysticism.

"Death of Colors" is the first collection of Sepehri's poetry which was published in 1951 and revised and republished a few years later. As it can be inferred from the title, the poems of "Death of Colors" have been created under the impact of the social and political life of the era prior (omitted a space) to the August 18, 1953 Coup. This is highly turbulent 
period in the history of Iran. In this period, the majority of the poets are tended to use dark symbols such as night, darkness, loneliness, silence, cold, tyranny, defeat, dictatorship, imprisonment (omitted the commas) and the like in their poetry. Presumably, Sepehri has contributed to this situation by writing "Death of Colors". He was also like his contemporary engaged in rejecting his cultural tradition and in becoming increasingly alienated from the dominating traditions of classical literature.

Sepehri has tried to express the chaotic and unstable situation of the time during the time of writing "Death of Colors". As Abedi (entered a space) (1995) believes, at this period Sepehri was seeking a solution for his ambivalent world. "In "Death of Colors", Sepehri has not succeeded in formulating and presenting a definite plan of his thought (p.97) ". He is immersed in his mysterious world, trying to find his silver lining out of the cloudy world of his time. Sepehri has cast a gloomy glance at the nature. As Abedi (entered a space) (1995) asserts "... the poet has some connection with nature but this connection is only caused by his boredom with life and society"(p.111). He seems depressed and (omitted then) abstains from society or community without even considering the possible purpose or goal of social relationships and patterns of interaction. This detachment is aptly considered in his book.

(omitted a space)He feels solitude and depression. In the "Wall", he is conveying this pessimistic view. The word "Wall" is one of the recurring words in the Persian contemporary poetry. Mehdi Sharifian (2005), in his article "Consideration and Description of Symbols in Sohrab Sepehri's Poems", has explored the second meaning of Sepehri's symbols. In this regard, he believes that "Wall is used to describe a state of solitary confinement". As it is clear, Sepehri is stuck in a period of inertia and stagnation. He finds himself alone in a desert and feels so estranged that cannot even recognize the voice of his footsteps anymore. He is reflecting on the nature but he is disturbed and frightened. The universe is dead for the poet even the sound of his footsteps are lost in this nature.

In the desert that I was marching

Neither a bird's wing disturbed the clear air

Nor the sound of my footsteps like other nights

Added to the sound of my former steps (Sepehri, 2007.pp.51-52).

At this point, Sepehri is bewildered and reluctant to make a connection with the outer word. Therefore, he decides to confine himself in an enclosed space by building a "Wall" around himself.

To raise a solid and firm wall around me

I brought from distance, rocks sold and heavy, bare footed

I built a lofty wall in that place

To hide everything that to my eye was base

And to shut the passage to attacking giants

That in my mind I had visualized (Sepehri, 2007. pp.52-52)

This could be inferred that the thought of reconciliation a new connection with the society has led the poet to building a wall around himself in a desert. Also from a different perspective, he is conscious of being abandoned and feels incapable of doing anything other than totally secluding himself behind a wall. The complete paralysis of his will is symbolized by his demand of bricking an imaginary wall around himself. By building this wall, he is determined to deprive himself of all the ugliness of the society specifically those thought which has hindered the passage he had visualized in his mind.

Sepehri has lost his hope and is filled with sadness in his poems of "Death of Colors" .Mehdi Sharifian (entered a space) (2005) has asserted that "Color is the symbol of hope, ambition and brightness which are the effect of opening the eyes to the spirits of nature". This justifies the reason as to why Sepehri is using "Death" as a modification for "Color" in the title of his first collection. Moreover, he has used the same title for one of his poems. In this poem which seems to epitomize the spirit of this book, Sepehri is focused on the description of the word "Color". He is referring to his state of stagnation by saying that "Some color by the night/ Has wordless died"(Sepehri, 2007. pp. 54). His "Color", which is his hope, ambition and brightness, is dying without having a chance to express his reason.

These sadness and hopelessness are tinged with frustration and depression. He is overcome in a moment of despair and solitude. He expresses his feelings in these words "A black bird comes from far way/ sings atop the roof of night's fall/ in rapturous triumph has come/ this bird woebegone"(Sepehri, 2007. pp.55). Furthermore, by referring to the tune of this bird, he is expressing the silence prevailing him: "The tone of the reckless bird alone/decks the ear sheer silence" (Sepehri, 2007. pp.55). Sepehri is lost in a period of hopelessness and feels a sense of loss while his dreams are shattered "A bar has fallen/ a dream is broken/ The dream of the land has forgotten/ The fable of the blooming roses of color"(Sepehri, 2007. pp.55).

The poet is utterly desperate and driven to a state of inactivity or as Mores Peckham (entered a space) (1962) says a "static mechanism". In another poem entitled "Man and Sea", the poet is not even reacting to the blowing wind which is an emblem of great change. He is indifferent to the blowing wind and when the wind, which is personified here, asks the man about his destiny, it receives no answer:

"Terrifying wind

Turns his face to the shore, and into the eyes of the man 
Enriches the color of danger

It seems

Wind says: "hey man, where are you heading to?"

And man walks on his way

And the wandering wind

It says: "hey man, where are you heading to?"

And man walks on his way

So does the wandering wind"(Sepehri, 2007. pp.57-58).

Shahrokh Hekmat (entered a space) (2011) in his article "Myth Representation and Some of its Function in Sorab Sepehri's Poem" asserts that wind is the source of creative imagination and a radical change. He believes "wind is a mythological term which is the sign of acquiring knowledge by crossing a bridge to the eternal time and place". Then, this could be seen that the wind is totally neglected by the poet in the "Man and Sea". This could be considered as a typical romantic wind which symbolizes change in psychological condition. But Sepehri's indifferent attitude toward the wind shows his unwillingness to change and progress. According to Morse Peckham (entered a space) (1962), his situation can be described as one who is experiencing "spiritually death"(p.243). Sepehri is left desolate and isolated as "a wanderer, a pilgrim without any shrine to go to"(p.245). Morse Peckham asserts that "The typical symbols of negative romanticism are individuals who are filled with guilt, despair, and cosmic and social alienation"(p.247). These features are abounding in Sepehri's "Death of Colors". Therefore, one can infer that Sepehri is experiencing "negative romanticism" before experiencing romanticism or as Peckham says "positive romanticism".

As it is easily noticed, Sepehri's first collection of the poem is abounding with dark and gloomy images. However, these feelings of doubt, despair and social alienation cannot be seen in his second collection of poems. Sepehri's second collection of poems was published in 1953. By entitling it "The Life of Dreams", Sepehri aims at showing a change in his attitude. While his first collection was filled with dark images, in his second collection, life has replaced death as illuminating elements are supplanted by light, the Sun (omitted the commas) and lantern. This collection signifies the fact that the poet seems to have found his way and has left the static state of "Death of Colors". Coincidentally, it is at this time that Sepehri learns about mysticism in the east: "In this collection he enters the world of mystic contemplation" (Abedi as cited in Emad, 1999, p. 44). Sepehri's acquaintance with the world of mysticism has functioned as a shifting phase for Sepehri. The next poems show that Sepehri is not going to apply darkness and grief. The darkness echoed in his "Death of Colors" seems to fade away and move towards light. "Sepehri has resolved his paradoxes and has broken all his connection with the surrounding world"(Abedi, 1999, p. 123). From now on, Sepehri is solely focused on his own internal world.

"I drew the image of my dream

My eyes losing the dangling anchor in its daze

How could you pour all the warmth of last eve's dream

in the spaceless arteries of this image?

I drew my sketch/Something was lost

I bent over me:

A hollow in my being gaped"(Sepehri, 2007. pp.86).

Sepehri is not lost in the external world anymore and has found himself within himself. At this moment, he is searching for the truth within himself. As one examines more closely the poems of this collection, it could be seen that Sepehri is more certain about the path he has selected. He is trying to empty himself of all the worldliness "My window opened to the void/And I was ruined/The screen was breathing/' (Sepehri, 2007. pp.88-89). The void, of which Sepehri speaks, is an extreme turning away from society. Sepehri is trying to look away from the external acts and towards the area of inner attitudes and motivation for a true understanding. He is linked to inner moral purification. The emphasis is rather on inner transformation so that destructive and decisive traits can be destroyed, making way for their opposites to flourish. "O tarred wall! /Vanished away/Bitter end of hypnotic sounds! / crumble down" (Sepehri, 2007. pp.89).

Sepehri's thought reached a state of complete deadlock in his first book and he was stuck in static state. However, he found his way in his second book, though (omitted the semi-colon) he is not totally aware of its ending. In this regard, Morse Peckham(1962) describe this situation as the time when "A man moves from a trust in the universe to a period of doubt and despair of any meaning in the universe, and then to a re-affirmation of faith in cosmic meaning and goodness, or at least meaning"(p.243). In "Death of Colors", Sepehri lost his faith in the universe but he regained his faith in the "The Life of Dreams". Now, he can grasp meaning out of his world after the sign of alienation and despair are vanished away.

Besides writing these collections of short poems, Sepehri has written two long poems which are mostly the manifestation of his thought and have held him a central place in Persian contemporary poetry. These two long poems are entitled "The Sound of the Water's Step" and "Traveler". Sirus Shamisa (entered a space) (1993) believes that " 'Traveler' is written two years after 'The Sound of the Water's Step' and logically it is a continuation of that poem, (omitted a space) however, it is more complicated and internal"(p.120). Here, it is aimed to explore the second poem 
"Traveler" to see the final cycle of Sepehri's thought in writing poem. This poem is the development of Sepehri's thought into the best possible form and shows his fully grasp of "positive romanticism".

"Traveler" is written in three hundred eighty lines, consisting of thirty-five stanzas. A poem with such length and shape is almost unprecedented in the history of Persian literature and this could considered as the poetics of "New Poetry" since long poems of classical Persian literature are either romances or didactical stories filled with allegories and storytelling. The first part of the poem is formed by a dialogue between a host and his guest while the second part is regarding the traveler's experiences on his journey. During this conversation, the traveler is telling of his religious experiences. The poem is abounding with mystical elements. Moreover, the word "Traveler" is significant in mystic writings.

The thirteen-century poet Mahmud Shabestari, who has elaborated on mystic vocabularies, has defined the word "Traveler" as a perfect man. This does not mean that the poem should only be interpreted in Sufi terms but it can give us some hints of what Sepehri probably had in mind of his "Traveler". In Sufi context, there will be a union between the perfect man and the immaterial beloved, however, Sepehri has insisted that "There remains always a distance"(Sepehri, 2007. pp.308). Sirus Shamissa (entered a space) (1993), in his book "A Look at Sohrab Sepehri", has extensively elaborated on this poem. He has asserted that "Traveler is a symbol of a person who is not stuck in one specific situation and is like running water passing through different stages in search of truth; he behaves the same as those Sufis who were in search of the truth in the past"(p. 31). Shamissa has explicitly declared that Sepehri has not stayed at one particular juncture of his life time to be forever bewildered whereas he has struggle to change and grow out of this bewilderment.

In "Traveler", Sepehri recounts his story vividly in the first section of the poem until he comes to a pivotal point when he says "I come from sun's companionship/Where is shadow?" (Sepehri, 2007. pp.319). Though Sepehri does not believe in the union of the lover and immaterial beloved, he is telling us he has totally comprehended the vastness of his immaterial beloved which is his ultimate aim, in other word, he has "apprehended the truth intuitively, imaginatively, spontaneously with whole personality, from the deep sources of fountain that are within"(Peckham, 1962, 240).

Surely, "Sun" is a symbol of his apprehension of truth which he has been yearning for during his life. He is telling us of a truth of which he was deprived when he had been writing his first collection of poems. And he is totally indulging in its comprehension at this moment. He is not negligent of the wind anymore whereas he is casting himself over to it "And I am the sole subjects of the world's wind"(Sepehri, 2007. pp.320). He put himself at the central point of the blowing wind which is the means for a radical change while he was not even answering to it in his first book. He is now welcoming wind with open arms: "In Sepehri's poem, wind imports wisdom and provokes memory and thought"(Shamissa, 1993, p. 162). This can justify the reason Sepehri is casting himself to wind. It can elevate him and endow him with great thoughts. It seems Sepehri has totally abandoned his "static mechanism" and has arrived at "a reintegration of thought and art in terms of 'dynamic organicism"'(Peckham, 1962, 242).

\section{Conclusion}

A final description, analysis and evaluation of Sepehri's thoughts have been difficult to reach. There always could be some new interpretation of his poetry at a time. His poetry has been explored at different levels, however, there is still much to be done before reaching a certain point in his poetry. In few researches in Iran, Romantic elements have been discussed and explored. These are mostly based on natural elements which are the prominent features of Sepehri's poetry and English Romanticism. Nonetheless, there has not been a research tracing the development of Romanticism in his poems, in the similar way, Morse Peckham has done in his famous article "Toward a Theory of Romanticism".

In his article, Peckham tries to simplify the term Romanticism by subdividing it into two terms of negative and positive Romanticism. His main reason behind this division is to show a change of poet's mind when he is shifting his phase. Peckham defines the "static mechanism" as opposed to "dynamic organicism" which is endowed with values of "change, imperfection, growth, diversity, the creative imagination, the unconscious"(Peckham, 1962, 241) and points out that the most prominent feature of European Romanticism is the redirection of European mind to think in terms of "dynamic organicism". This is precisely what Sepehri has undergone during writing his Hasht Ketab or The Eight Books.

In writing "Death of Colors", Sepehri was thinking in terms of static mechanism. He was lost in his surrounding and was a stranger to everything happening around him. He could not find a lead to follow and this generated a period of bewilderment and ambivalence which hindered his course of action. But he came to a change in his course of action when he was acquainted with Far Eastern mysticism. This acquaintance paved a new way before him to discover. After that his dark and pessimistic attitude toward the external world was faded away and he pivoted his attention on his internal world. This change which is considered as a shift from negative romanticism to positive romanticism in terms of Morse Peckham, granted Sepehri a fresh outlook toward world which ended in writing his masterpiece "Traveler", a poem which has achieved the highest caliber in Persian contemporary poetry.

\section{References:}

Abedi, k. (1997). Az Mosahebate-e Aftab: Life and Works of Sohrab Sepehri.Tehran:Sales.

Ashouri, D., Emami, K., \& Hamedani, H. M. (1992). A message on the way. Tehran: Tahouri. 
Farzan, M. (1984). "The Neo-Sufic Poetry of Sohrab Sepehri". Critical Perspectives on Modern Persian Literature, p.455.

Hekmat, S. (2011), "Myth Representation and Some of its Function in Sorab Sepehri's Poem", Journal of Literary Thoughts.2th edition, no. 6. 147-159.

Hosseini, S. (2000). The silent lotus. Tehran: Niloufar.

Ja'fari, Mas'ood (2007). From Constitutional Revolution to Nima Yushij. Tehran:Nahsre-e Markaz.

Khazayeefar, A. (2006). "Sohrab Sepehri and William Wordsworth: Two poets of Self-Unity". Nameh Farhanstan. 8th edition, no. 2, 62-83

Lovejoy, O. A. (1962)." On the Discrimination of Romanticism." In Romanticism: Points of View. Ed. Gleckner \& Enscoe. London:Prentice Inc, (66-81).

\section{8).}

Meghdadi B. (1998). Analysis and the Selected Works of Sohrab Sepehri. 1st edition. Tehran: Paya.

Peckham, M. (1962). "Toward a Theory of Romanticism". In Romanticism: Points of View. Ed. Gleckner \& Enscoe. London:Prentice Inc, (231-258).

Pouralifard, A. (2003). "European Romanticism and Persian New Poetry." Journal of College of Literature and Humanities, Tabriz, 46, no. 187.

Shamisa, Sirus (1993). A Look at Sepehri. 3rd Edition. Tehran: Morvarid Press.

Shariati Rad, F., Royanian, S. (2014), Nature as the Source of Wisdom in Sepehri and Wordsworth's Poetry, Scholars Journal of Arts, Humanities, and Social Science, 2, 471-474.

Sharifian, M. (2007), Consideration and Description of Symbols in Sohrab Sepehri's Poems, Journal of The Faculty of Letters and Humanities, 21, 59-84.

Taslimi, A. (2004). Selections from Contemporary Iranian Literature (Poetry). Tehran: Akhtaran Press.

Wellek, R. (1962). "The Concept of Romanticism in Literary History." In Romanticism: Points of View. Ed. Gleckner \& Enscoe. London: Prentice Inc, (257-278).

Wellek, R., \& Austin W. (1949).The Theory of Literature. New York: Harcourt \& Brace Company.

Zarabihha, M.E. (2004). A Fresh Look: A Comprehension Interpretation of Eighth Book. Tehran: Bina Del Press. 